\title{
HEART BLOCK ASSOCIATED WITH CONGENITAL MALFORMATION OF THE HEART.
}

BY

G. B. FLEMING, M.D., F.R.F.P.S., AND MARY M. STEVENSON, M.A., M.D.
(From the Medical Department, Royal Hospital for Sick Children, Glasgow.)

Heart Block in congenital malformation of the heart is comparatively rare. The following two cases came under observation in the Royal Hospital for Sick Children, Glasgow.

CASE 1. D. H., male, aet. $3 \frac{1}{2}$ years. The labour was normal and the child was full term and healthy at birth. Except for a mild attack of measles when $1 \frac{1}{2}$ years old and a burn at the age of a year and nine months, he was quite healthy and throve well until 3 months before admission to hospital when he had a " bad turn" lasting all night. During this he became pale and unconscious and his mother thought his "heart had stopped." Since then he has appeared very tired at night and his appetite has been poor.

On admission to hospital he was found to be a fair-sized moderately nourished boy. He did not appear ill. His height was $91.5 \mathrm{c.mm}$., and he weighed $11.89 \mathrm{~kg}$. The skin was clear. There was no clubbing of the fingers nor cyanosis. Examination of the lungs, abdomen, nervous system and urine was negative. The tonsils were enlarged and the teeth carious.

The heart was enlarged, the apex beat being in the 5 th space 3 inches from the middle line, the left border of cardiac dullness $3 \frac{1}{2}$ inches from the midline, the right border 1 inch to the right of the midline and the upper border at the level of the third rib. Radiograms showed increased heart shadow both to the right and to the left. The cardiac pulsations were forcible. A loud systolic murmur was heard all over the præcordia. This was best heard midway between the apex and the midline; it was fairly well conducted to the axilla but was also conducted towards the right shoulder. The second sound was double both at the apex and the base. The heart rate was 46 per minute. The von Pirquet, Wassermann and the Schick tests were negative. The blood culture was sterile. The hæmoglobin was 78 per cent. (Haldane) and the red cells numbered 4,200,000 per c.mm. On making a fluoroscopic examination of the heart the auricles could be seen beating at an independent and more rapid rate than the ventricles.

The boy remained under observation in hospital for four months and during this time his pulse rate varied between 30 and 60 per minute, only occasionally rising to slightly over 50, but never falling below 30 per minute. Even when the child was up and going about, it rarely exceeded 50 per minute. During his stay in hospital the boy's general condition improved greatly but the condition of the heart remained unchanged. There were no syncopal nor cyanotic attacks.

CASE 2. Female, aet. 8 years. The child was very small at birth, weighing only $4 \mathrm{lb.,}$ but seemed healthy. She was always small and delicate; she did not walk till three years of age and did not talk till five. When one year old it was noticed that the hands, feet, lips and cheeks were blue and that the fingers were becoming clubbed. Ever since she began to walk she has had frequent fainting attacks. She has never been able to walk quickly and has always been easily tired.

On admission to hospital she was found to be a spare child weighing $22.7 \mathrm{~kg}$. The hands, feet, lips and cheeks were definitely cyanosed and the fingers and toes were clubbed. There was rhinitis. The lungs were clear. The liver could be felt two finger-breadths below the costal margin. The heart was enlarged. The apex beat was in the 5 th space, $2 \frac{3}{4}$ inches from the midline, the left border of cardiac dulness was $3 \frac{1}{2}$ inches to the left and the right border $\frac{3}{4}$-inch to the right of the midline, the upper border on a level with the third rib. A loud systolic murmur could be heard all over the præcordia with its maximum intensity at the third left costal cartilage and was well conducted to the left clavicle. Behind, the murmur was well heard in the left inter-scapular region at the level of the 4th vertebra and was well conducted towards the left scapuia. There was slight fever on admission and the pulse rate at first was between 80 and 
90 per minute. On the third day in hospital the pulse rate fell to 60 and thereafter, until dismissal, remained between 45 and 65 with occasional rises to 85 per minute. Throughout her stay in hospital there were no syncopal attacks and the cardiac condition remained unchanged. There were 6,100,000 red cells per c.mm. and the hæmoglobin was 99 per cent. The von Pirquet and Wassermann reactions were negative. The child was backward mentally, her mental ratio being 56 (Binet Simon).

The patient was discharged from the hospital in August, 1922, and subsequently came under the care of Dr. Cowan at the Glasgow Royal Infirmary to whom and Dr. Rennie we are indebted for the electrocardiographic records. She was under observation there, at intervals, for several years without there being any notable change in the condition. Subsequently she died at home. There was no post-mortem examination.

In Case 1 it is possible that the cardiac lesion was acquired during some acute infection, e.g., unrecognized diphtheria. We know, however, that the bradycardia had been present when the child was twenty-one months old, for he then suffered from burns and was admitted to the Victoria Infirmary, Glasgow. On admission there his pulse rate was 72 per minute, but within three days it fell to 48 per minute and remained about 50 per minute during the remainder of his stay in that hospital. This, in conjunction with the evidence of congenital malformation of the heart afforded by physical examination, makes it practically certain that the bradycardia is of congenital origin.

From the history of Case 2 it is certain that the cardiac lesion had existed since infancy, but unfortunately we have no early records of the pulse rate.

\section{EleCtroCARDIOGRAPHIC RECORDS.}

CASE 1. Complete and permanent a.v block was present (Fig. 1). The auricular rate varied from about 80 per minute to 125 per minute, and the ventricular from about 35 to 50 per minute. The rhythm of the ventricles was almost regular and that of the auricles slightly irregular. On one occasion an auricular beat failed for no apparent cause (Fig. 2), and on another occasion ventricular beat was missed; this was after exertion (Fig. 3).

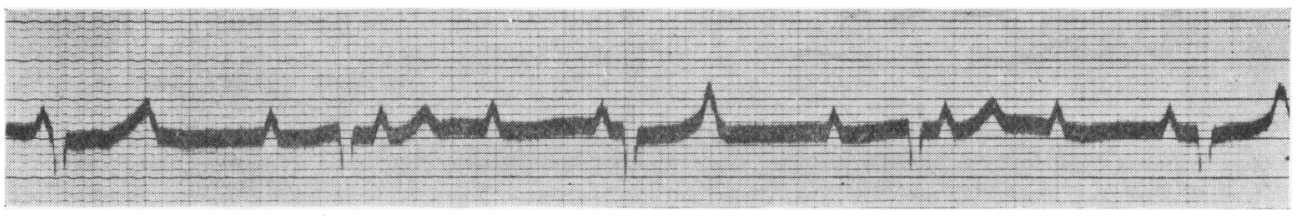

Fıc. 1. Case I. ? Complete dissociation of auricular and ventricular contractiuns

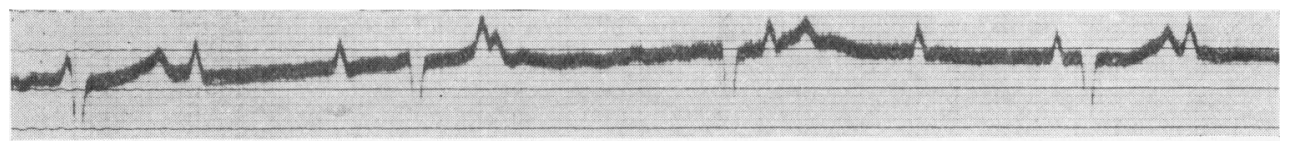

Fic. 2. Case 1. Asystole of the auricles

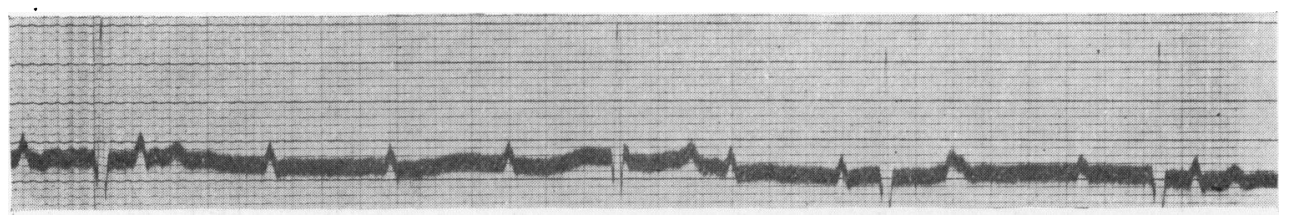

Fig. 3, Case I. Asystole of the ventricles 
The $\mathbf{P}$ deflections are large and seem quite normal, as also do the Q.R.S. deflections except where they are interfered with by one of the $P$ deflections. The $Q-T$ interval is prolonged measuring slightly over $0 \cdot 4$ second. The $\mathrm{T}$ deflection is positive in leads I and II, but sometimes inverted in lead III.

The effects of exertion and the. injection of atropine and of adrenalin were studied. The block was quite unaltered by any of these procedures. Tables I, II and III give the rates of the auricles and ventricles inımediately before and after each.

TABLE I.

The Effect of Exertion.

\begin{tabular}{|c|c|c|c|c|c|c|c|}
\hline & & & Before. & $\begin{array}{l}\frac{1}{2} \min . \\
\text { after. }\end{array}$ & $\begin{array}{l}1 \text { min. } \\
\text { after. }\end{array}$ & $\begin{array}{l}2 \text { mins. } \\
\text { after. }\end{array}$ & $\begin{array}{l}3 \text { mins. } \\
\text { after. }\end{array}$ \\
\hline $\begin{array}{l}\text { Auricle } . \\
\text { Ventricle }\end{array}$ & $\begin{array}{l}\cdots \\
\cdots\end{array}$ & $\begin{array}{l}\cdots \\
\cdots\end{array}$ & $\begin{array}{l}89 \\
37\end{array}$ & - & $\begin{array}{l}97 \\
\mathbf{3 9}\end{array}$ & $\begin{array}{l}95 \\
? *\end{array}$ & $\begin{array}{l}98 \\
39\end{array}$ \\
\hline $\begin{array}{l}\text { Auricle ... } \\
\text { Ventricle }\end{array}$ & $\begin{array}{l}\cdots \\
\cdots\end{array}$ & $\begin{array}{l}\cdots \\
\cdots\end{array}$ & $\begin{array}{l}98 \\
39\end{array}$ & $\begin{array}{r}123 \\
41\end{array}$ & $\begin{array}{r}100 \\
40\end{array}$ & $\begin{array}{r}103 \\
40\end{array}$ & - \\
\hline
\end{tabular}

*Asystole of the ventricle.

TABLE II.

The Effect of Atropine gr. $1 / 200$.

\begin{tabular}{lll|c|c|c|c|c|c}
\hline & & Before. & $\begin{array}{c}9 \text { mins. } \\
\text { after. }\end{array}$ & $\begin{array}{r}19 \text { mins. } \\
\text { after. }\end{array}$ & $\begin{array}{c}26 \text { mins. } \\
\text { after. }\end{array}$ & $\begin{array}{c}40 \text { mins. } \\
\text { after. }\end{array}$ & $\begin{array}{c}45 \text { mins. } \\
\text { after. }\end{array}$ \\
\hline Auricles. & $\ldots$ & $\ldots$ & 86 & 93 & 86 & 98 & 104 & 107 \\
Ventricles & $\ldots$ & $\ldots$ & 36 & 44 & 36 & 43 & 38 & 49
\end{tabular}

TABLE III.

The Effect of Adrenalin 0.5 cc. 1 in $1,000$.

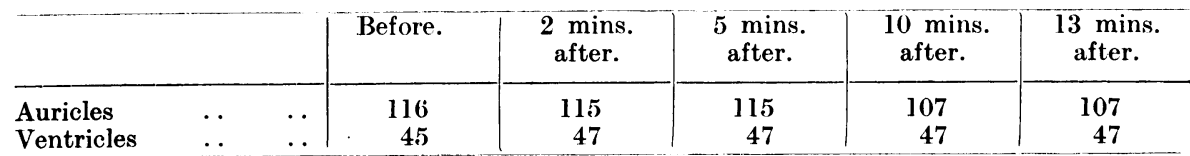

The exertion consisted in the patient raising himself rapidly to a sitting position in bed and lying down again 20 times ; this was sufficient to make him slightly out of breath. It will be noted that the auricular rate was slightly increased but that there was practically no alteration in the ventricular rate.

After the injection of $1 / 200 \mathrm{gr}$. of atropine there was a definite increase in the rate of both the auricles and the ventricles. Half an hour after the injection of the drug the patient showed definite signs of its action, flushed dry skin and dilated pupils, but the block persisted. $\frac{1}{2}$ c.cm. of adrenalin ( 1 in 1,000$)$ injected subcutaneously had practically no influence on the ventricular rate, but there was slight slowing of the auricular rate. These tests exclude the possibility that the block was of nervous origin. Pressure on the vagus in the neck was tried on two occasions. This had no effect on the rate or rhythm of the radial pulse.

The results of these tests show almost certainly that there was a complete hiatus in the conducting fibres somewhere between the auricles and the ventricles, the probability being that there was atsence of that part of the inter-ventricular septum through which the a-v bundle passes.

CASE 2. The curves show 2-1 block, the auricular rate being twice that of the ventricular, every second auricular beat being blocked (Fig. 4). The $Q$ deflection is present and the R.T. interval is not unduly prolonged. The $\mathrm{T}$ deflection is positive in all leads. Very similar curves were obtained in Wilson and Granț ${ }^{1}{ }^{1}$ case, 


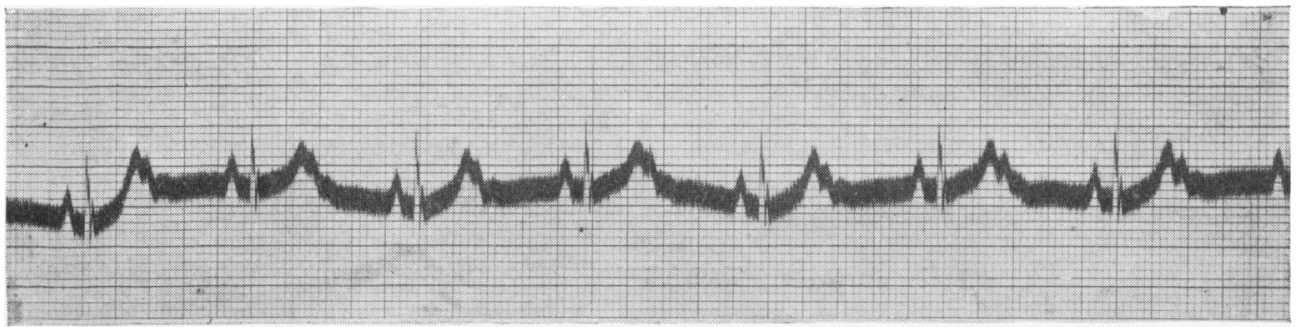

Frg. 4. Case II. 2-1 Heart Block. The blocked auricular contractions immediately follow the $T$ waves

The effect of exertion and the injection of atropine are shown in Tables IV and V. After the pulse rate had been increased by exertion and the giving of atropine the $T$ wave became single (Fig. 5). It seems clear that the blocked $P$ wave became completely fused with $T$. This seems the most reasonable explanation of the disappearance of the blocked $\mathrm{P}$ wave for it is extremely unlikely that the action of either atropine or exertion would be to slow the auricular rate. This view is confirmed by tracings taken on one occasion immediately after exertion where there was irregularity (Fig. 6). In this curve each physiological beat is followed by a ventricular extra systole and in the long pause following this a blocked auricular complex can be clearly seen.

TABLE IV.

\section{Pulse Rate.}

Before exertion
Immediately after exertion
l minute after exertion

TABLE V.

Pulse Rate.

\begin{tabular}{|c|c|c|c|c|c|c|c|c|}
\hline & . & $\ldots$ & & 5 \\
\hline \multicolumn{5}{|c|}{$\begin{array}{l}\text { Berore atropine gr. } 1 / 00 . \\
1 \frac{1}{2} \text { minutes after } . .\end{array}$} & $\ldots$ & . & . & 5 \\
\hline $5 \frac{1}{2}$ & ,", & ,, & . & . & $\ldots$ & $\ldots$ & . & 5 \\
\hline 9 & , & , & . & . & . & . & . & 52 \\
\hline 13 &., & ,, & . & . & . & . & . & 64 \\
\hline 14 & , & ,' & . & $\cdots$ & . & $\cdots$ & $\cdots$ & 66 \\
\hline 19 &, & , & .. & . & . & . & $\ldots$ & 78 \\
\hline
\end{tabular}

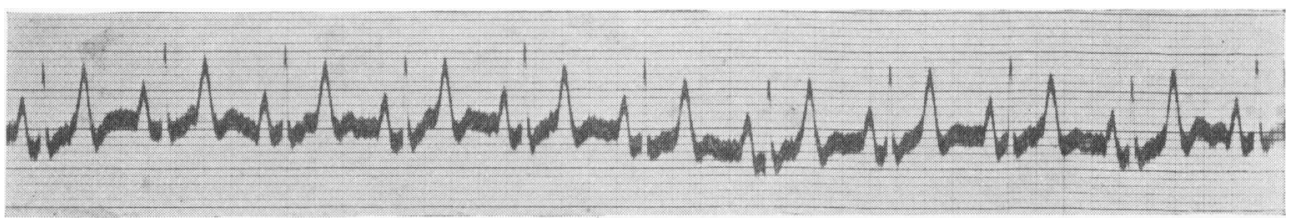

Fig. 5. Case II. After atropine the blocked $P$ waves fuse with $\mathbf{T}$

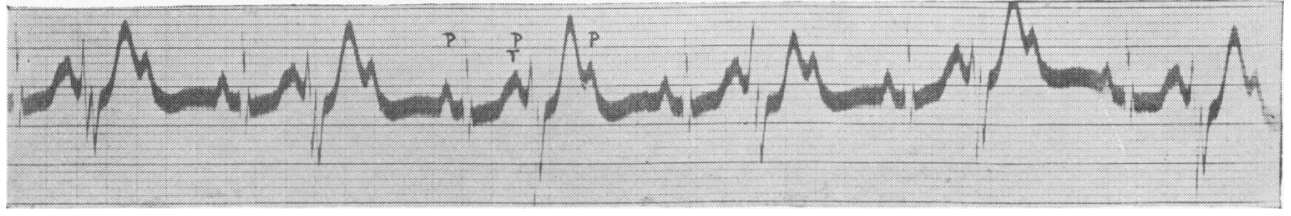

Fic. 6. Case II. After exe"tion the heart's action becomes irregular. A normal beat is followed by an extra systole and in the long pause succeeding this a blocked $P$ wave can be seen 


\section{Discussion.}

The cardiac deformity most likely to produce heart block is absence of, or defect in, the upper part of the inter-ventricular septum and although this is the most common cardiac deformity (Abbott ${ }^{2}$ ) congenital heart block seems to be rare. Probably the fact that the usual site of the septal defect is anterior to the pars membranacea whilst the a-v bundle lies behind it, explains the comparative rarity of the condition. In the only case in which a post mortem examination of the junctional tissues has been made (Wilson and Grant's ${ }^{1}$ case) there was a gross defect in the ventricular septum and the fibres of the bundle were found to be seriously affected, though there was still a tenuous connection of primitive tissue between the auricles and the ventricles. In this case there was partial (2-1) block. There is a striking resemblance between this and our second case. In both there was cyanosis and clubbing of the fingers, in both the cardiac signs pointed to pulmonary stenosis, and in both the electrocardiogram showed 2-1 block, the T-wave being split by the blocked P-wave.

We have been able to trace in the literature records of nineteen authenticated cases. The first twelve of these have been summarized by White, Eustis and Kerr ${ }^{3}$. Since then cases have been reported by Rhomberg and White ${ }^{4}$ (one case), Frias ${ }^{5}$ (one case), Barbier, Lebée and Mouquin ${ }^{6}$ (one case), Wilson and Grant ${ }^{1}$ (one case), Lukin and Frey ${ }^{7}$ (one case), McIntosh ${ }^{8}$ (one case) and Nessé $^{9}$ (one case), while recently Schlesinger ${ }^{10}$ has reported a case in which there was branch bundle block. The majority showed complete a-v block (16 cases) while in three the block was partial. In the cases where the block was complete the pulse rate showed a tendency to vary inversely with the age. All the cases under one year of age had a pulse rate of between 72 and 60 per minute; the four between one and three years had rates varying between 66 and 37 ; in those between six and fifteen years the rate varied between 48 and 37 except in one case where a child of eight years had a pulse rate of 20 per minute. In the two adults, aged 22 and 23 years, the pulse rates were 43 and 34 respectively.

Cyanosis, dyspnœa and syncopal attacks are not prominent features of the condition, and their occurrence is probably dependent on the extent of the cardiac deformity rather than on the degree of block.

The two cases described in this paper fall into line with those previously recorded. They both presented physical signs compatible with defect in the inter-ventricular septum, and in Case 2 other lesions probably of congenital origin (e.g., pulmonary stenosis) were present. In the first case there was no disability except for the history of syncope three weeks before admission. In the second, however, cyanosis, clubbing of the fingers, dyspnœa on exertion and syncopal attacks are recorded. All these might well be accounted for by the magnitude of the cardiac deformity. In Case 1 neither atropine, adrenalin nor exertion influenced the block in the slightest degree, and in Case 2 it is clear that neither exertion nor atropine abolished the block.

From a study of the literature it seems probable that congenital heart block is confined to cases where there is a defect in the inter-ventricular septum 
and that in the absence of gross cardiac deformities the block per se causes little or no disability. It is, however, not always easy to say definitely that the block is of congenital origin. A considerable number of cases of heart block in children following the acute infections have been described, but where a history suggesting such a cause is lacking, and where there are definite physical signs of congenital deformity, the probability is strongly in favour of a congenital origin for the block.

In view of the fact that practically all the cases presented physical signs suggestive of patent inter-ventricular septum, and that of all deformities this is the one most likely to interfere with the normal course of the a-v bundle, it seems probable that the presence of heart block in congenital heart disease is an important positive sign of defect of the posterior part of the interventricular septum.

\section{SUMMARY.}

Two cases of heart block in congenital deformity of the heart are described.

In one the block was complete and in the other it was partial. In neither case was the block of nervous origin. Cyanosis and dyspnœa were present in one case but not in the other.

The probable lesions were patent inter-ventricular septum and maldevelopment of the a-v bundle, though in both cases there may have been other cardiac deformities.

\section{REFERENCES.}

1. Wilson, J. G., and Grant, R. T., Heart, Lond., 1926, XII, 295.

2. Abbott, M., Osler W., and McC'rae, T., Modern Medicine, London, 1927, IV, 687.

3. White, P. 1)., Eustis, R. S., and Kerr, W. J., Am. J. Dis. Child., (hic., 1921, XXII, 299.

4. Rhomberg, E. C. and White, P. D., Bost. Med. and Surg. J., Boston, 1924, CXC, 591.

5. Frias, J. B., quoted by Abbott, loc. cit., 667.

6. Barbier, Lebée and Mouquin, Arch. d. Mal. de Coeur, Paris, 1922, XV, 171.

7. Lukin, N. and Frey, D., Arch. of Ped., N.Y., 1927, XLIV, 646.

8. McIntosh, R., Am. J. Dis. Child., Chic., 1927, XXXIV, 965.

9. Nissé, B. S., Proc. Roy. Sor. Med., London, 1928, XXI (Clin. Sec.), 438.

10. Schlesinger, B., Proc. Roy. Soc. Med., London, 1927, XXI (Sec. Dis. of Child), 215. 